\title{
Enhancing Africa's Growth and Sustainable Development through Innovation and Technology Transformational Model
}

\author{
Bassey Asuquo Ekanem, Elizabeth Bassey Ekanem
}

\begin{abstract}
Technology and innovation are essential enablers for growth and sustainable development. Over the years, there have been conscious efforts by Africans in the area of innovation and technology enhancement as evident in Remitta and M-Pesa for financial services, Way-C tablet in communications, M-Kopa in Energy, and Twiga in Agriculture and Food inclusion just to mention but a few. However, even with these efforts, Africa is still ranked low in global innovation index (GII). In fact, the highest ranked African countries namely Mauritius, South Africa, Tunisia and Kenya are placed $52,60,65$ and 86 respectively out of 131 countries. This research was designed to investigate the factors responsible for the low GII as well as recommend ways of enhancing it. Based on the research findings, Innovation and Technology Transformational Model is presented as a veritable tool for enhancing Africa's innovation and technology capacities to ensure growth and sustainable development.
\end{abstract}

Index Terms - Growth and Sustainable Development, Global Innovation Index, Innovation Potentials, Innovation and Technology Transformational Model

\section{INTRODUCTION}

Nations with great global positive impacts are those with high innovation and technology capacities carefully harnessed in their operations. Same with regions, organizations and even individuals. Innovation is not just about having ideas, but about being able to transform ideas into practical reality in the form of innovative products and services. Developed nations like United States of America, United Kingdom, Switzerland, Canada and others are ranked high in global innovation index (GII) because of their innovation capacities and outputs [1]. Although African countries are ranked below the first 50 countries, Africa's consciousness of the impact of innovation and technology in growth and sustainable development is very high as evident in various innovative products like Remitta and M-Pesa in financial services, M-Kopa in Energy, Twiga in Agriculture and Food inclusion among others developed by Africans [2].

Apart from these widely celebrated products, there are thousands of other innovative products created by talented Africans and showcased annually at different expositions

Bassey Asuquo Ekanem, Computer Science Department, Delta State Polytechnic, Ozoro, Delta, Nigeria

Elizabeth Bassey Ekanem, Department of Science Laboratory Technology, Delta State Polytechnic, Ozoro, Delta, Nigeria
(Expos) all over the continent [3]. Also, to awaken the consciousness of the youths to the impacts of innovation and technology, many Techno Camps and hubs are usually set up annually where youths are gathered, trained and guided on how to create innovative products. An example of such programmes include Africa Science week - a weeklong event in 35 African countries for students that are usually trained on renewable energy, Arduino programming and others. Also, worthy of note is the Annual Techno Expos by Federal Ministry of Science and technology, in some African countries whereby young inventors showcase their innovative products [4]. Another is The Young Inventors Summer Camp - a one month holiday technology training program for secondary school students are usually organized where the students are trained on electronic circuit design, mobile App Design, Web Design, TV and Media production [5].

The big question therefore is, with these thousands of innovative products created and showcased at various techno Expos by Africans, how many have been adequately enhanced and commercialized to contribute to GII and by extension, growth and sustainable development of the continent? Your guess is as good as mine, possibly less than $1 \%$ of the showcased produced will be developed. Most times, at the end of the Techno Training and Expo programs, the ideas are abandoned and the products forgotten. A lot of factors could have been responsible for this particularly poor technology and innovation management and lack of funding [6]. Additionally, some that even scale the hurdles and find their ways into the markets as innovative products suffer low market acceptance and patronage, hence the inventors are discouraged from continuing.

These challenges faced by young innovators continually limit their capacities to innovate and by extension lowers Africa's global innovation index as evident in the 2020 GII report where African countries are not listed among the top 50 ranked innovative countries/economies whereas the nearest is placed at the 52nd position [7]. Similarly, in terms of innovation output sub index, the 2020 global IDI indicates that Africa in not among the 50 top ranked countries, the highest ranked country is placed at the 59th position. Furthermore, available reports indicate that the curriculum used in teaching students in higher institutions of learning are inadequate or completely lacking in contents for training them in innovation and technology management [6]. 
Although, there is upward movement of the highest ranked African country from 57 in 2018 to 52 in 2020 GII ranking, the above highlighted low indexes and many others, point to the fact that a lot needs to be done to reposition Africa on the path of innovation and technology for growth and sustainable development.

In view of the above, this research was designed to investigate Africa's innovation and technology landscape with the view to identifying the missing links and ways of addressing them for growth and sustainable development.

\section{REVIEW OF LITERATURE}

Efforts by Africans to enhance growth and sustainable development of the continent through innovation and technology are well known with Remitta, M-Pesa and many others as referenced products [2]. Efforts by governments at various levels and philanthropists in enhancing innovation and technology in Africa are also well noted with Young Inventors Summer Camps, Africa Science week as typical examples [3], [4] and [5].

The impact of these efforts on the Global innovation index of African countries is notably not as expected although not without a ray of hope for some countries like Mauritius, South Africa, Tunisia and Kenya that are placed 52nd, 60th, 65th and 86th respectively out of 131 countries [1]. That Switzerland, Sweden, USA, United Kingdom, Netherlands, Singapore, Republic of Korea, China and Canada are placed amongst the top ranked 20 innovative countries/economies is not surprising as indicated in their level of innovation and technology capacities as well as their innovation outputs.

According to [8], Switzerland continued placement at the topmost position is because of her capacities to innovate efficiently by translating investments in education, research and R\&D expenditures into high-quality innovation outputs. Same goes for other high ranked countries like Luxembourg, Ukraine, Malta, Germany, and Sweden which are amongst the top ranked 20 countries.

The fact that countries leading in global innovation index and by extension growth and sustainable development are those with capacities to translate investments in education, resear tputs clearly affirms the importance of innovation capacities in countries growth and sustainable development. Also, the place of research in innovation and technology cannot be over-emphasized. Innovations with great momentums are those backed by research to address the immediate needs of the people as witnessed in M-Pesa and Remitta used for financial services in some African countries [2] and [6].

The initial stages of Innovation lifecycle named Ideas and Concepts are research intensive. Also, the first stage of Technology Life Cycle called Research and Development (R\&D) involves a lot of research [9]. It's through these stages that customer requirements, market potentials, chances and market entry barriers could be determined and adequately addressed [10]. Africa' research funding and corresponding outputs in terms of world's research funding and research outputs as reported by [11] and [12] are $1.3 \%$ and $2 \%$ respectively which are grossly inadequate. This in effect, has a great negative impact on Africa's quest for innovation and technological advancement where research is a key factor. In fact, without research, there is no innovation.

Quality research can only be conducted by trained personnel, implying that quality education is key in conducting quality research capable of producing quality outputs needed to bring about growth and sustainable development. Quality education will enhance the research potentials of the researchers by equipping them with the skills for conducting quality research to identify innovation potentials for growth and sustained development.

Lack of quality education for the vast majority of Africans is a barrier to Africa's innovation and technology advancement. Also, inadequate education infrastructure in African institutions has forced most talented Africans into oversee studies where they enjoy world-class higher education. Such individuals may not return to Africa after their studies, rather chose to remain abroad and contribute to the growth and development the foreign countries from generation to generation through their innovative skills - a case in point is Philip Emeagwali, a Nigerian- American computer scientist who invented the CM-2 massive parallel computer. Where this happens, as it usually happens, Africa loses and the foreign country gains [2].

\section{FINDINGS FROM THE REVIEW}

The review indicates that research is a catalyst for innovation; without research, there is no innovation. According to [1] and [8] Switzerland continued to occupy the first position in GII ranking due to her increased capacities to innovate efficiently by translating investments in education, research and R\&D expenditures into high-quality innovation outputs. Sweden, USA, United kingdom, Netherlands, Singapore, Republic of Korea, China, Canada and Luxembourg also possess this capacity, hence comfortably enjoying the top 20 positions in the GII ranking. Apart from research, the level of investment in education as well as R\&D expenditure are key elements for successful innovation.

As a further confirmation of the place of research in innovation, a report presented in [1] indicates that China's 14th position in 2020 up from 17 in 2018 represents a breakthrough for an economy witnessing rapid transformation guided by government policies with emphasis on research and development inline with stages 1 and 2 of innovation and technology lifecycle. Without research, one 
cannot find innovation potentials let alone developing it into technology [13].

In applying the three elements as in the case of Africa, it is a known fact that, educational facilities in African countries are inadequate for training talented Africans on technology and innovation let alone providing the required opportunities needed to translate investments in education, research and $R \& D$ expenditures into high-quality innovation products for growth and sustainable development of the continent. Worst still, Africa's R\&D expenditures, quality of research and research outputs are far lower than those of the top ranked countries. The review clearly indicates that poor education infrastructure; inadequate research, poor research funding and low research outputs as well as low transformative capacities, low technology infusion; and inappropriate government policies are the major factors militating against Africa's progress in technology and innovation advancement.

In the words of Buckminster Fuller, 'you never change things by fighting the existing reality. To change things, build a new model that makes the existing model obsolete' [14]. Therefore, there is the need for a new model that is capable of changing Africa's course in the direction needed to encourage innovation and technology advancement towards growth and sustainable development of the continent.

\section{RESEARCH METHODOLOGY}

The research was conducted following the methods and stages outlined below:

i) Literature Review - this was undertaken to gain more understanding of the subject matter being investigated.

ii) Research Design - focused on specifying research objectives, hypothesis, research questions and methodology.

iii) Design of Research Instrument - in this stage, a closed-ended questionnaire with relevant questions and predefined options was designed.

iv) Review and Validation of Questionnaire undertaken by experts in technology-related discipline and statisticians to ascertain the suitability of the instrument for the research.

v) Distribution of questionnaires to respondents via online platforms - email and WhatsApp platforms were used. Respondents were sourced through Snowball sampling technique.

vi) Data Analysis - conducted using Pearson's Chi-squared test and statistical package like MS Excel.

vii) Interpretation of Results and appropriate recommendations.

\section{RESEARCH DATA}

The research data for this were collected through email platform by forwarding the research questionnaire to the respondents who completed and returned them. The snowball sampling method was used to identify the respondents who were drawn basically from 6 African countries namely Nigeria, Mauritius, South Africa, Ghana, Kenya and Benin Republic. The selected respondents are professionals in different spheres of human endeavours mainly from the Science, Technology, Engineering, Business and other areas as indicated in table 1. A total of 1278 valid questionnaires were returned by the respondents.

\section{Table 1: Characterisation of the Respondents}

\begin{tabular}{|l|l|r|}
\hline S/n & Professional Area & $\begin{array}{l}\text { No. } \\
\text { Respondents }\end{array}$ \\
\hline 1 & Science & 312 \\
\hline 2 & Engineering & 296 \\
\hline 3 & Technology-related & 308 \\
\hline 4 & Business & 234 \\
\hline 5 & Agriculture & 85 \\
\hline 6 & Arts and Humanities & 43 \\
\hline Total & & $\mathbf{1 2 7 8}$ \\
\hline
\end{tabular}

Table 2 presents the summary of the respondents' feedback to the twelve positivistic statements with SA = Strongly Agree, $\mathrm{A}=$ Agree, $\mathrm{UD}=$ Undecided, $\mathrm{D}=$ Disagree and $\mathrm{SD}=$ Strongly Disagree as applicable. 
Enhancing Africa's Growth and Sustainable Development through Innovation and Technology Transformational Model

Table 2: Summary of Respondents' Feedback

\begin{tabular}{|c|c|c|c|c|c|c|c|}
\hline 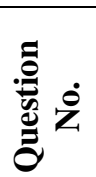 & Statement & SA & $\overline{\mathbf{A}}$ & UD & D & SD & total \\
\hline Q21 & $\begin{array}{l}\text { Africans innovation and technological advancement } \\
\text { could be enhanced when supported by } \\
\text { transformative capacities }\end{array}$ & 1028 & 227 & 23 & 0 & 0 & 1278 \\
\hline Q22 & $\begin{array}{l}\text { Innovation and Technology Management could } \\
\text { positively impact Africa's Technological } \\
\text { Advancement }\end{array}$ & 1035 & 224 & 19 & 0 & $\mathbf{0}$ & 1278 \\
\hline $\mathbf{Q 2 3}$ & $\begin{array}{l}\text { Challenges associated with Africa's Technological } \\
\text { Advancement are better addressed with innovation } \\
\text { and transformative capacities. }\end{array}$ & 1057 & 210 & 11 & 0 & $\mathbf{0}$ & 1278 \\
\hline Q24 & $\begin{array}{l}\text { Educational Curriculum in Africa's tertiary } \\
\text { institutions are inadequate in Innovation and } \\
\text { Technology capacity building }\end{array}$ & 1159 & 110 & 9 & 0 & $\mathbf{0}$ & 1278 \\
\hline Q25 & $\begin{array}{l}\text { Innovation and Technological advancement for } \\
\text { Africa's growth and development will be effective } \\
\text { when supported with quality research and adequate } \\
\text { research funding }\end{array}$ & 1036 & 219 & 23 & 0 & $\mathbf{0}$ & 1278 \\
\hline Q26 & $\begin{array}{l}\text { Massive investment in technology transfer by } \\
\text { Africans could accelerate transformative capacities } \\
\text { for Africa's growth and development }\end{array}$ & 1106 & 160 & 12 & 0 & $\mathbf{0}$ & 1278 \\
\hline Q27 & $\begin{array}{l}\text { Innovative products from African innovators are } \\
\text { relatively few compared to those of the developed } \\
\text { economies }\end{array}$ & 1121 & 137 & 20 & 0 & $\mathbf{0}$ & 1278 \\
\hline $\mathbf{Q 2 8}$ & $\begin{array}{l}\text { Innovative products from African Innovators do not } \\
\text { enjoy global patronage due to low product quality }\end{array}$ & 1028 & 227 & 23 & 0 & $\mathbf{0}$ & 1278 \\
\hline Q29 & $\begin{array}{l}\text { Innovative products from African Innovators usually } \\
\text { fail at the Market Introduction stage due to low } \\
\text { patronage }\end{array}$ & 1141 & 124 & 13 & 0 & $\mathbf{0}$ & 1278 \\
\hline Q30 & $\begin{array}{l}\text { Challenges associated with acceptability of African } \\
\text { innovative products are better addressed with } \\
\text { transformative capacities. }\end{array}$ & 1006 & 251 & 21 & 0 & $\mathbf{0}$ & 1278 \\
\hline Q31 & $\begin{array}{l}\text { Technological Infrastructures deployed in most } \\
\text { African countries are inadequate to support } \\
\text { technology and innovation }\end{array}$ & 1118 & 145 & 15 & 0 & $\mathbf{0}$ & 1278 \\
\hline & Total & 11835 & 2034 & 189 & 0 & $\mathbf{0}$ & 14058 \\
\hline
\end{tabular}




\section{DATA ANALYSIS}

Analysis of the collected data was perform accordingly to test the following Hypothesis designed for the research:

$H_{I}$ : Africa's Growth and Development is significantly influenced by her level of innovation and technology capacities.

The analysis was conducted with Pearson's Chi-squared test. The observed frequency table constructed from the data is given in Table 3.

The expected frequency table based on the collected data was constructed using the expression

$$
\begin{aligned}
E_{i j} & =\frac{r_{\mathrm{i}} X C_{j}}{G T} \ldots \ldots \ldots \ldots \ldots \ldots \ldots \ldots \\
E_{11} & =\frac{1278 X 11835}{14058}=1075.9
\end{aligned}
$$$$
E_{12}=\frac{1278 \times 2034}{14058}=184.9
$$$$
E_{13}=\frac{1278 X 189}{14058}=17.18
$$

Table 3 shows $\chi^{2}$ cal values obtained from eqn. 2

$$
\chi_{\text {cal }}^{2}=\sum_{i=1}^{n}\left[\frac{\left(o_{i}-E_{i}\right)^{2}}{E_{i}}\right] \ldots \ldots . .(\text { eqn. } 2)
$$

Table 3: Observed Frequency Table from the Data

\begin{tabular}{|c|c|c|c|c|}
\hline $\mathbf{O}_{\mathbf{i}}$ & $\mathbf{E}_{\mathbf{i}}$ & $\left(\mathbf{O}_{\mathrm{i}}-\mathbf{E}_{\mathrm{i}}\right)$ & $\left(\mathbf{O}_{\mathrm{i}}-\mathbf{E}_{\mathrm{i}}\right)^{2}$ & $\left(\mathbf{O}_{\mathrm{i}}-\mathbf{E}_{\mathrm{i}}\right)^{2} / \mathrm{E}$ \\
\hline 1028 & 1075.9 & -47.9 & 2294.41 & 2.13 \\
\hline 1035 & 1075.9 & -40.9 & 1672.81 & 1.55 \\
\hline 1057 & 1075.9 & -18.9 & 357.21 & $\mathbf{0 . 3 3}$ \\
\hline 1159 & 1075.9 & 83.1 & 6905.61 & 6.42 \\
\hline 1036 & 1075.9 & -39.9 & 1592.01 & 1.48 \\
\hline 1106 & 1075.9 & 30.1 & 906.01 & 0.84 \\
\hline 1121 & 1075.9 & 45.1 & 2034.01 & 1.89 \\
\hline 1028 & 1075.9 & -47.9 & 2294.41 & 2.13 \\
\hline 1141 & 1075.9 & 65.1 & 4238.01 & 3.94 \\
\hline 1006 & 1075.9 & -69.9 & 4886.01 & 4.54 \\
\hline 1118 & 1075.9 & 42.1 & 1772.41 & 1.65 \\
\hline 227 & 184.9 & 42.1 & 1772.41 & 9.59 \\
\hline 224 & 184.9 & 39.1 & 1528.81 & 8.27 \\
\hline 210 & 184.9 & 25.1 & 630.01 & 3.41 \\
\hline 110 & 184.9 & -74.9 & 5610.01 & 30.34 \\
\hline 219 & 184.9 & 34.1 & 1162.81 & 6.29 \\
\hline 160 & 184.9 & -24.9 & 620.01 & 3.35 \\
\hline 137 & 184.9 & -47.9 & 2294.41 & 12.41 \\
\hline 227 & 184.9 & 42.1 & 1772.41 & 9.59 \\
\hline 124 & 184.9 & -60.9 & 3708.81 & 20.06 \\
\hline 251 & 184.9 & 66.1 & 4369.21 & 23.63 \\
\hline 145 & 184.9 & -39.9 & 1592.01 & 8.61 \\
\hline 23 & 17.18 & 5.82 & 33.8724 & 1.97 \\
\hline 19 & 17.18 & 1.82 & 3.3124 & 0.19 \\
\hline 11 & 17.18 & -6.18 & 38.1924 & 2.22 \\
\hline 9 & 17.18 & -8.18 & 66.9124 & 3.89 \\
\hline 23 & 17.18 & 5.82 & 33.8724 & 1.97 \\
\hline 12 & 17.18 & -5.18 & 26.8324 & 1.56 \\
\hline 20 & 17.18 & 2.82 & 7.9524 & 0.46 \\
\hline 23 & 17.18 & 5.82 & 33.8724 & 1.97 \\
\hline 13 & 17.18 & -4.18 & 17.4724 & 1.02 \\
\hline 21 & 17.18 & 3.82 & 14.5924 & 0.85 \\
\hline 15 & 17.18 & -2.18 & 4.7524 & 0.28 \\
\hline \multicolumn{4}{|c|}{$\chi_{\text {cal }}^{2}$} & 178.84 \\
\hline
\end{tabular}

\begin{tabular}{|l|r|r|r|r|r|r|}
\hline $\begin{array}{c}\text { Questi } \\
\text { on No. }\end{array}$ & SA & A & UD & D & SD & Total \\
\hline Q21 & 1028 & 227 & 23 & 0 & 0 & 1278 \\
\hline Q22 & 1035 & 224 & 19 & 0 & 0 & 1278 \\
\hline Q23 & 1057 & 210 & 11 & 0 & 0 & 1278 \\
\hline Q24 & 1159 & 110 & 9 & 0 & 0 & 1278 \\
\hline Q25 & 1036 & 219 & 23 & 0 & 0 & 1278 \\
\hline Q26 & 1106 & 160 & 12 & 0 & 0 & 1278 \\
\hline Q27 & 1121 & 137 & 20 & 0 & 0 & 1278 \\
\hline Q28 & 1028 & 227 & 23 & 0 & 0 & 1278 \\
\hline Q29 & 1141 & 124 & 13 & 0 & 0 & 1278 \\
\hline Q30 & 1006 & 251 & 21 & 0 & 0 & 1278 \\
\hline Q31 & 1118 & 145 & 15 & 0 & 0 & 1278 \\
\hline Total & 11835 & 2034 & 189 & 0 & 0 & 14058 \\
\hline
\end{tabular}

Table 4: Calculated Values based on Data

$\mathrm{df}=(\mathrm{r}-1)(\mathrm{c}-1)$ where $\mathrm{r}$ is row (i.e. number of questions) and $\mathrm{c}$ is column (i.e. number of options in the response). In this case $(11-1)(3-1)=20 ; \quad \alpha=0.05$ $\chi_{\text {tab }}^{2}=\chi_{20}^{2}, 0.05=31.410$ 


\section{RESULTS AND DISCUSSIONS}

The following are the summary from the Pearson's Chi-squared test performed:

Chi-squared calculated value $=178.84$, degree of freedom $(\mathrm{df})=20$ and

Chi-squared tabulated value $=31.410$;

From the above, it can be clearly stated that since the $\chi_{\text {cal }}^{2}$ is greater than $\chi_{\text {tab }}^{2}$, we accepts the logical hypothesis that Africa's Growth and Development is significantly influenced by her level of innovation and technology capacities. This implies that, Africa's growth and development could be enhanced with corresponding enhancement in innovation and technology capacities.

Reflecting on the challenges presented earlier, it is very obvious that enhancing innovation and technology capacities for growth and sustainable development requires a model that incorporate:

i) World-class education infrastructure in institution of learning;

ii) Quality research

iii) Increased research funding

iv) Quality research outputs

v) increased funding of technology and innovation activities;

vi) appropriate government policies for driving technology and innovation;

vii) adequate infrastructure to support technology and innovation,

viii) technology infusion

In view of the above, the model Innovation and Technology Transformational model is presented.

\section{INNOVATION AND TECHNOLOGY TRANSFORMATIONAL MODEL}

In dealing with Africa's innovation and technology challenges highlighted earlier, a model named Innovation and Technology Transformational Model is presented in this article as a tool to enhance Africa's innovation and transformative capacities for growth and sustainable development. The model has four stages with Quality Research as the initial and crucial stage of the model. This stage is crucial because, quality and effective research is capable of producing innovation potentials needed to create innovative products. Therefore, innovative capacity would be enhanced when quality researches are conducted to identify innovation potentials required to create new products, technology and services.

The success of this stage depends on the following elements: quality education in institutions of learning to equip learners with skills needed to conduct quality research, standard research infrastructures in research institutes and institutions of higher learning, increased funding of research proposals with innovation potentials, quality research policies and quality research outputs from researches undertaken.

Once innovation potentials have been successfully identified through quality research, the second stage called Innovation follows. The success factor for this stage is to move from low hanging fruits to the high hanging counterparts. This could be achieved by classifying identified innovation potentials into potentials for short-term innovation and potentials for long-term innovation and carefully reviewing and acquiring the technology required to transform the ideas into practical reality. By way of distinction, potentials for short-term innovation are those that require existing technology to innovate, potentials for long-term innovation are those that require new technologies to work and such have to be acquired (created) through long term projects.

In stage three - the Technology stage, the acquired technology is used to create and support innovative products and services stem from the generated ideas. To fast track innovation and technological advancement, there is need to leverage on existing technology to create the products and services from potentials for short term innovation. Innovations potentials requiring existing technology like Information Technology and others in the local environment are candidates for this. Being that such technologies are already in place and being used for one function or the other, leveraging on such to drive innovation will be easier and faster than creating a new technology for it.

However, for long-term innovation potentials, developing such could be done gradually through long-term projects since they will require huge investments and complex processes. Through a careful application of the acquired technology, the final stage called Innovative Products is reached where innovative products with high acceptability and market penetration (both locally and globally) are created. Moving in this manner, from one successful innovative product to another and in quick succession with a plan to create more over a specified period of time will no doubt enhance Africa's GII and by extension her growth and sustainable development. 


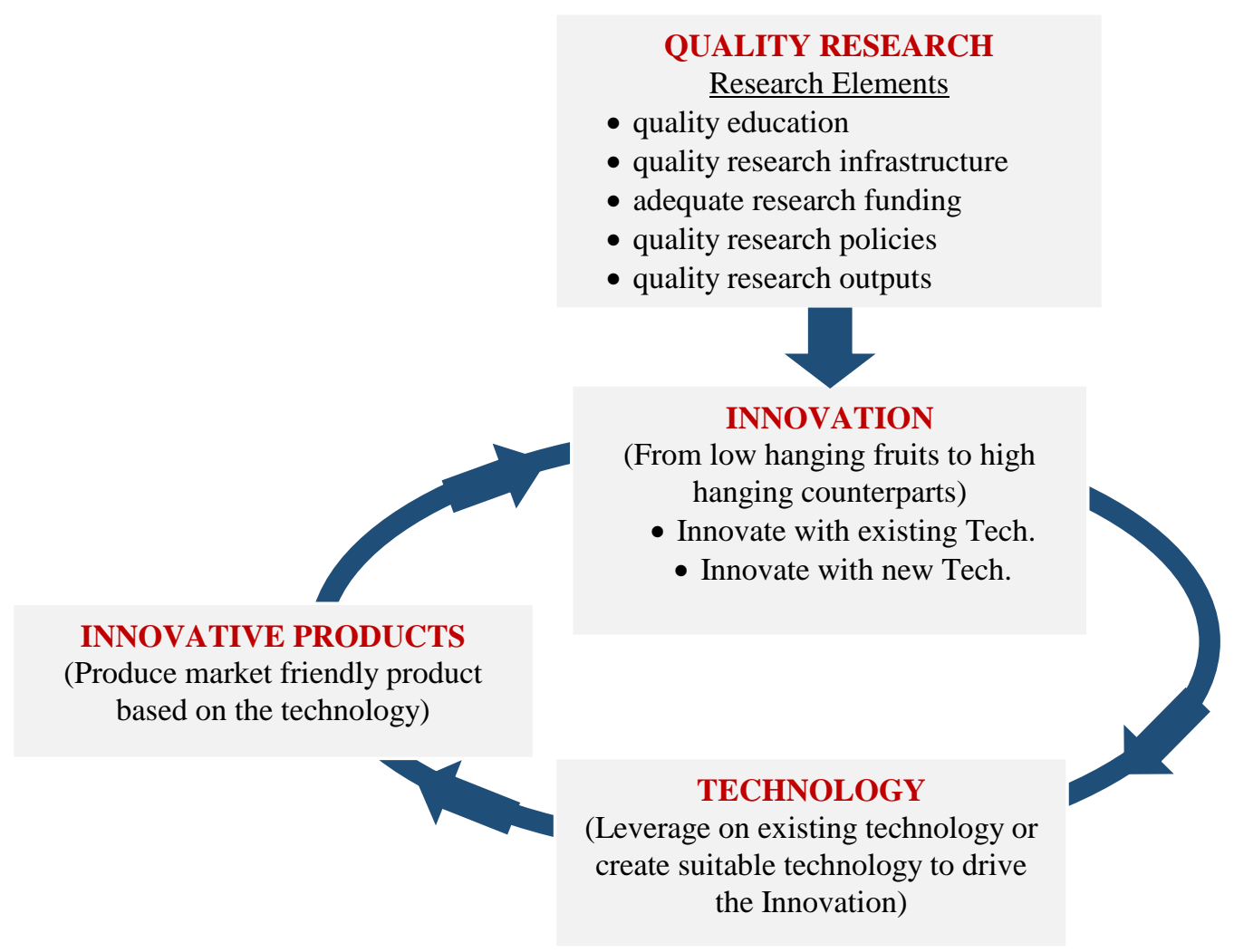

Figure 1: Innovation and Technology Transformational Model

\section{CONCLUSION}

The task of addressing innovation and technology gaps in Africa for growth and sustainable development is achievable. With conscious efforts by stakeholders focussing on low hanging fruits, Africa could enhance her GII and by extension fast track her growth and sustainable development through innovative products. Quality education, quality research, adequate research funding and right government policies are some of the basic requirements for this to be achieved.

\section{RECOMMENDATIONS}

The following recommendations are key to addressing the huge gaps in Africa's Innovation and Technological advancement:

i. A Continental Innovation and Technology Management Body saddled with the responsibilities of addressing common innovation and technological challenges among African nations should put in place

ii. Government should ensure that policies formulated to drive public and private businesses in respective countries are well designed to promote innovation and technology enhancement.

iii. Quality Research even with continental collaboration should be encouraged to identify innovation potentials in the continent for further development. There should be a machinery in place to encourage sharing of innovation and technology experiences among member nations.

iv. Measures should be put in place by governments of each country to identify, encourage and finance innovation and technology projects with great potentials for growth and sustainable development undertaken by individuals or groups.

v. Innovation and technology education with huge practical and industrial exposure for the youths should encouraged with the introduction of innovation and technology management courses at all levels of education to stimulate innovation, invention and technology management amongst the learners.

\section{ACKNOWLEDGMENT}

We wish to acknowledge the Rector of our institution, Prof. Akpodiete O. J. for his supports and encouragements which make it possible for us to conduct this research. We also wish to acknowledge the contributions of our friends Dr. J. Meye and Engr. Dr. O. Eboibi which made this research a success.

\section{REFERENCES}

[1] WIPO, "Global Innovation Index 2020: Rankings 2020" World Intellectual Property Organization, New York, pp. 33, September, 2020 Available: https://www.wipo.int/global_innovation_index/en/2020 Access Date: 10 February, 2021

[2] A. Gurib-Fakim, "Technology and Development in Africa: Innovation for Sustainable Growth", Chatham House, The Royal Institute of International Affairs, 2017 Available:

https://www.chathamhouse.org/sites/default/files/events/Transcri pt\%20-\%20Technology\%20and\%20Development\%20in\%20Afr ica\%20-\%20Innovation\%20for\%20Sustainable\%20Growth.pdf Access Date: 5th February, 2019

[3] J. Ikpesu, "Africa Science Week 2018 - Nigeria; Working to Advance STEM Education for African Women (WAAW) Foundation", 2018' Available:

http://waawfoundation.org/2018/10/30/african-science-week-201 8-nigeria/ Accessed Date: 23rd May, 2020 
[4] N. Isaac, "Techno Expo: Showcasing Nigeria's Strength in Science and Technology", Leadership Newspaper Blog, 2018 https://leadership.ng/2018/03/13/techno-expo-showcasing-nigeri as-strength-in-science-and-technology/ Accessed Date: 19th June, 2020

Premium Times "Techno Expo for Young Innovators set to hold in Lagos", 2019 Available:

https://www.premiumtimesng.com/news/more-news/281885-tec h-expo-for-younginnovators-set-to-hold-in-lagos.html January, 2019

Accessed Date: 10th

B. A. Ekanem, and E. A. Peter, "Nigeria Software Industry: Challenges and Potentials for Sustainable Growth" International Journal of Computer Applications 175 (17) pp. 24-31, 2020 Available:

https://www.ijcaonline.org/archives/volume175/number17/3154 5-2020920682

Accessed Date: 11th January, 2021

G. Padmashree, "Key issues for African countries in Science, Technology and Innovation", United Nations Conference on Trade and Development (UNCTAD) 2012.

WIPO "Global Innovation Index 2018: China Cracks Top 20 Top Rankings: Switzerland, Netherlands, Sweden, UK, Singapore, US", World Intellectual Property Organization, New York, 2018 Available:

https://www.wipo.int/pressroom/en/articles/2018/articles_0005.html Access Date: 12th March, 2019

[9] Boostlabs "Technology Life Cycle: When you should Engange Tech Trends", 2018 Available:

https://www.boostlabs.com/Technology-Life-Cycle-When-YouShould-Engage-Tech-Trends-Boost- Labs.htm Accessed Date: 5th February, 2019

M. Shahmarichatghieh, A. Tolonen, \& H. Haapasalo, "Product Life Cycle, Technology Life Cycle and Market Life Cycle; Similarities, Differences and Applications; Joint International Conference 2015 on Technology, Innovation and Industrial Management", 2015 Available:

https://www.boostlabs.com/Technology-Life-Cycle-When-You-

Should-Engage-Tech-Trends-Boost- Labs.htm

Accessed Date: 5th February, 2019

[11] World Economic Forum "The Inclusive Development Index 2020; Summary and Data Highlights 2020 Available: https://www.weforum.org/reports/the-inclusive-development-ind ex-2018

Access Date: 10th February, 2021

[12] J. F. Sargent, "Global Research and Development Expenditures: Fact Sheet; Congressional”, 2018 Available:

https://fas.org/sgp/crs/misc/r44283.pdf

Accessed Date: 10th February, 2021

[13] A. Hengsberger, "The 4 phases of innovation", LEAD

Innovation Management Blog, 2018 Available:

https://www.lead-innovation.com/english-blog/the-4-phases-of-i nnovation Access Date: 15th July, 2020

[14] R. B. Fuller, "R. Buckminster Fuller Quotes", Quotable Quotes, Good Reads, 2015 Available:

https://www.goodreads.com/quotes/13119-you-never-change-thi ngs-by-fighting-the-existing-reality-to

Accessed Date: 14th July, 2020

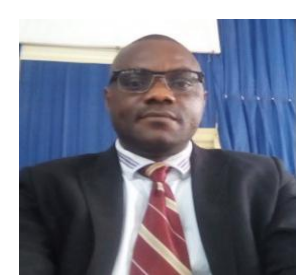

Author: Dr. Bassey Asuquo Ekanem is a holder of B. Sc. and M. Sc. degrees in Computer Science as well as $\mathrm{Ph}$. D. degree in Engineering and Technology Management. His research interest is in Software Engineering - software components reusability as well as Technology and Innovation. He is a member of Computer Professionals of Nigeria (CPN), Nigeria Computer Society (NCS) and IEEE. Ekanem is a certified Software Forensic expert using CodeSuite Application. He is a Chief lecturer with Delta State Polytechnic Ozoro teaching software engineering and related courses. He has published manner articles in the areas of software engineering, technology and innovation with particular note of "Legacy Components Stability Assessment and Ranking Using Software Maturity Index", Dealing with Components Reusability Issues as Cutting-edge Applications Turn Legacy, Nigeria Software Industry: Challenges and Potentials for Sustainable Growth and many others.

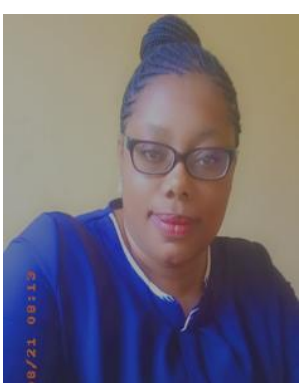

Author: Mrs. Elizabeth Bassey Ekanem is a staff of Science Laboratory Technology Delta State Polytechnic, Ozoro. She has B. Sc. Degree in Bio-Chemistry and M. Ed in Science Education. Her research interest is in Quality Education for Innovation and Technology. She is a member of Teachers Registration Council of Nigeria (TRCN). Some of her published articles include Enhancing Innovation and Technology in Nigeria through Enhanced Curriculum with Innovation and Technology Contents, The impact of Application of ICT in Administration of Polytechnics in Nigeria, The Impact of Applied Science Curriculum on Students' Training and Suitability for employment in Delta South Senatorial District and Chemical Composition of Diplazium Sammatii 'Nyama Idim'. 